\title{
Boken om Churchill
}

Jenkins R

Churchill

1001 s, ill. Oslo: Forlaget Historie \& Kultur, 2009. Pris NOK 478

ISBN 978-82-92870-16-7

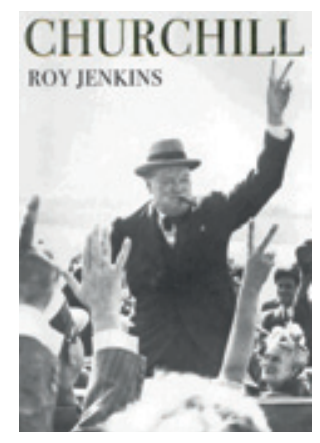

I 1966, året etter Churchills død, utga hans livlege en erindringsbok som vakte stor oppsikt (1). Boken ble raskt oversatt til norsk (2). Legen ble skarpt kritisert for å avsløre taushetsbelagt informasjon om den

døde pasienten.

Charles Wilson (1882-1977) var blitt lege for Winston Churchill (1874-1965) i 1940, og han fortsatte i denne funksjonen resten av Churchills liv. I 1943 ble han adlet, og det er som lord Moran han er kjent (3). Han var blitt 84 år gammel da boken kom ut, og må antakelig ha følt en forpliktelse overfor historien. Den regnes nå som en klassiker i livlegelitteraturen (4). Diskusjonen om hva som bør være offentlig kjent om kjentfolks helse, pågår fortsatt $(5,6)$.

Jeg ble minnet om lord Morans verk da jeg leste Roy Jenkins (1920-2003) monumentale Churchill-biografi. Den utkom på engelsk i 2001, to år før Jenkins døde, og det skulle gå åtte år før den ble oversatt til norsk. Jenkins, som hadde vært både innenriksminister og finansminister for Labour, skrev flere historiske bøker, bl.a. om 1800tallets største statsminister, Gladstone. Da han begynte å skrive om Churchill, mente han at Gladstone med snever margin var den største av disse to, men i løpet av skrivearbeidet ombestemte han seg. Jenkins avslutter med at Churchill var det største mennesket som noen gang har bodd i nr. 10 Downing Street.

Biografien er på ca. 1000 sider, inkludert noter (30 sider), bibliografi i utvalg, bildeliste og personregister. De medisinske sidene - og lord Moran - spiller naturlig nok en underordnet rolle i fortellingen. Jenkins klarer på mesterlig vis å forene omtalen av personen Churchill med den tiden han levde $\mathrm{i}$.

Hvordan blir lord Morans bidrag vurdert i ettertid? Biograf Jenkins er lunken. Han påpeker både livlegens indiskresjon og unøyaktighet. Lord Moran omtales første gang idet Churchill fikk et anginaliknende anfall: «Samme kveld fikk han et hjerteanfall. Etter å ha strevd med å åpne et vindu kjente han en dump smerte i brystet som gikk nedover venstre arm, og han ble svært kortpustet. For første gang var den fremstående legen sir Charles Wilson, som snart skulle bli lord Moran, en del av Churchills følge. Fordelen ved dette var at Churchill kunne konsultere ham neste morgen, men ulempen var at Moran [...] var så ivrig etter å spille en sentral rolle at han ikke bare var indiskré, men iblant også et upålitelig vitne.» (s. 696). Jenkins fremholder flere ganger at opplysningene som Moran gir, må tas med flere klyper salt. Han hadde bestandig en tendens til å overdrive hvor dårlig Churchill egentlig var, for å understreke hvor godt det lyktes ham å holde ham i live, hevder Jenkins (s. 884).

Det er av en viss medisinhistorisk interesse å lese hvilken behandling lord Moran ordinerte til Churchill. Morans opprinnelige diagnose var at Churchill led av «svake kransarterier», og for dette var lærebøkenes standardbehandling minst seks uker i sengen (s. 696). Lord Moran innså at slik behandling ikke lot seg gjennomføre i Churchills tilfelle.

Da Churchill ble alvorlig syk av lungebetennelse i 1943, telegraferte Moran «i alle retninger» etter legehjelp. Dette var visstnok en del av hans vanlige strategi. Da en sekretær spurte hva han skulle gjøre dersom Churchill ble syk når han var alene på vakt, fikk han følgende svar: «De ringer lord Moran, og han sender bud på en ordentlig lege» (s. 749).

\section{Erlend Hem}

erlend.hem@medisin.uio.no

Tidsskriftet

\section{Litteratur}

1. Lord Moran. Winston Churchill: the struggle for survival 1940-1965: taken from the diaries of Lord Moran. London: Constable, 1966.

2. Lord Moran. Winston Churchill: kampen for à overleve: av hans livleges dagbok 1940-1965. Oversatt av Nils Lie. Oslo: Gyldendal, 1966.

3. Lovell R. Churchill's doctor: a biography of Lord Moran. London: Royal Society of Medicine, 1992

4. Dahl NL. Livlegenes historie. Oslo: Universitetsforlaget, 2000: 131-5

5. Nylenna M. Kjentfolks helse - et offentlig anliggende? Tidsskr Nor Lægeforen 1997; 117 : 4279-81.

6. Markel H, Stern AM. Presidential health and the public's need to know. JAMA 2008; 299: 2558-60. http://jama.ama-assn.org/cgi/content/full/299/21/ 2558 (27.5.2010).

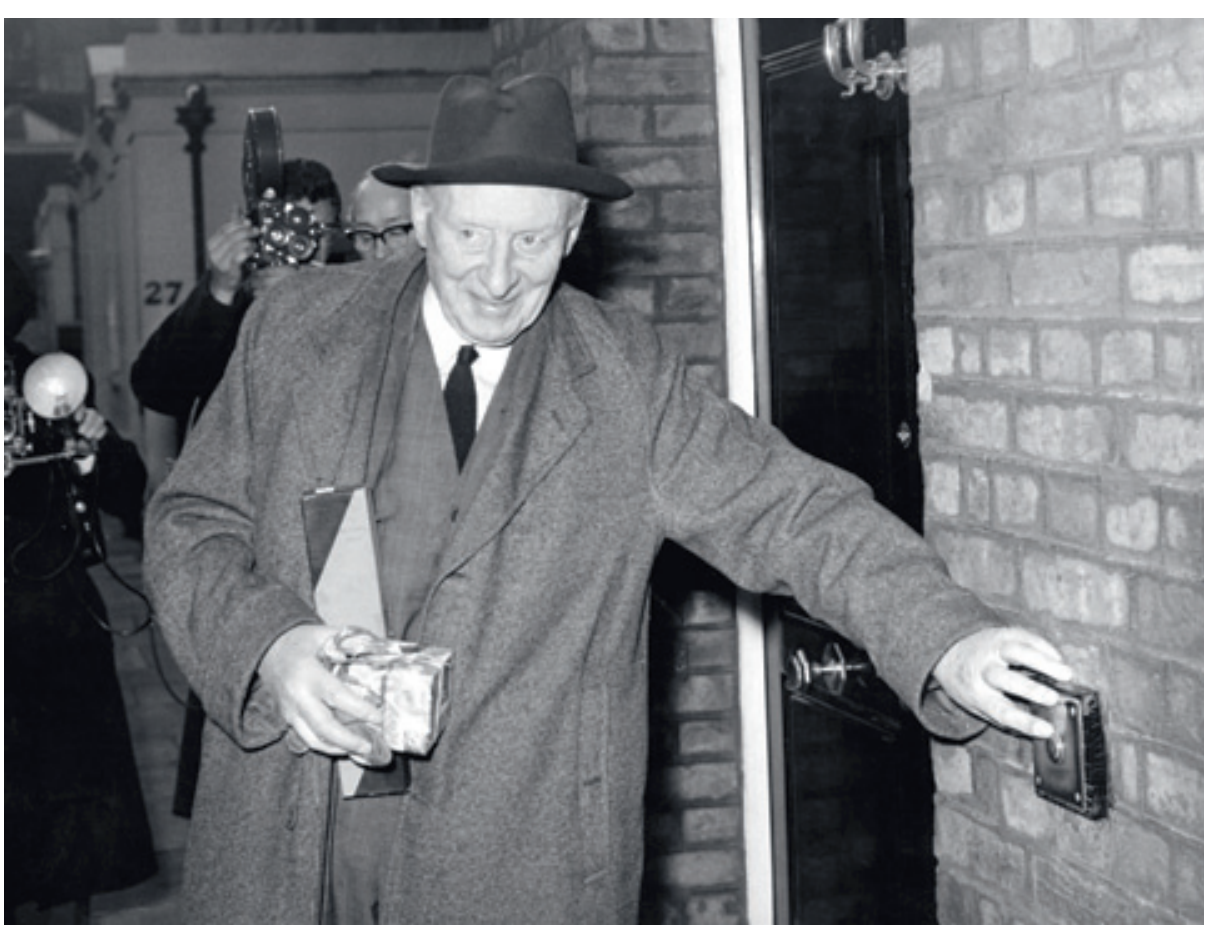

Figur 1 Lord Moran, sir Winston Churchills lege og venn, ringer på dørklokken i Churchills hjem i nr. 28 Hyde Park Gate på sir Winstons 88-årsdag 30. november 1962. Foto @ 2004 TopFoto/SCANPIX 